\title{
MIGRAÇÃO INTERNACIONAL PENDULAR EM FRONTEIRA: EM BUSCA DE QUALIFICAÇÕES ESPACIAIS
}

\section{INTERNATIONAL PENDULUM MIGRATION IN BORDER: IN SEARCH OF SPACIAL QUALIFICATIONS}

\author{
Marco Aurélio Machado de Oliveira' \\ Joanna Amorim de Melo S. Loio²
}

\begin{abstract}
RESUMO: O objetivo deste artigo é marcar no campo metodológico da migraçáo internacional a pendularidade em fronteira como aspecto relevante. Para tanto, entendemos que trabalhar com fronteira e migraçâo internacional como junçáo temática exige cuidados, pois ambas as categorias săo, comumente, carregadas de ideias advindas do senso comum que as localizam perifericamente nos entendimentos e discursos sobre a naçáo e a sociedade, tais como: provisoriedades, precariedades, ilicitudes. Os procedimentos metodológicos utilizados foram: revisăo bibliográfica visando adequaçôes às categorias abordadas; e, realizaçâo de entrevistas com sujeitos pendulares. O resultado foi a constataçấo de complexidades peculiares a esse grupo de imigrantes no espaço em que atuam.
\end{abstract}

Palavras-chave: Fronteira. Migraçăo Internacional. Pendularidade.

ABSTRACT: The aim of this article is to mark the methodological field of the international migration the pendularity in frontier as relevant aspect. To that end, we understand that working with border and international migration as a thematic junction requires care, since both categories are commonly loaded with common sense ideas that locate them peripherally in the understandings and discourses about the nation and society, such as: provisional, precariousness, unlawfulness. The methodological procedures used were: bibliographic review aiming at adaptations to the categories addressed; and, conducting interviews with commuting subjects. The result was the finding of complexities peculiar to this group of immigrants in the space in which they operate.

Key words: Border. International Migration. Pendulum.

1 Professor Titular na Universidade Federal de Mato Grosso do Sul, Doutor em História Social pela Universidade de Sáo Paulo, Docente Permanente do Mestrado em Estudos Fronteiriços (UFMS), membro do GT América Latina y Medio Oriente na CLACSO, E-mail: marco.cpan@gmail.com.

2 Psicóloga, Mestre em Estudos Fronteiriços/UFMS, Docente da Faculdade Salesiana de Santa Tereza. 


\section{INTRODUÇÃO}

O presente artigo tem como objetivo marcar no campo metodológico da migraçăo internacional a pendularidade em fronteira como aspecto relevante. Para tanto, entendemos que trabalhar com fronteira e migraçâo internacional como junçâo temática exige cuidados, pois ambas as categorias sâo, comumente, carregadas de ideias advindas do senso comum que as localizam perifericamente nos entendimentos e discursos sobre a naçăo e a sociedade, tais como: provisoriedades, precariedades, ilicitudes.

Diversos estudos têm apontado para as singularidades dos movimentos migratórios pendulares internacionais em regiôes de fronteira. Temos como exemplos os que indicam os impactos trazidos pelo fluxo e presença de migrantes internacionais na fronteira entre Espanha e Marrocos (DRIESSEN, 1998), que envolve tanto atividades laborais quanto de diversăo e lazer que, da mesma forma como na fronteira MéxicoGuatemala (FARFÁN, 2015), também, sâo sazonais. No caso que envolve o Magreb e a Europa, essa mobilidade foi denominada como 'new immigration', expressáo usada para enfatizar uma modalidade migratória muito pouco reconhecida na literatura na década de 1990. No exemplo centro-americano, 'migración transfronteriza' é a forma como os pesquisadores denominaram o movimento.

Por sua vez, 'Pendulum migration' foi a forma como os estudiosos, por meio de trabalhos desenvolvidos no âmbito do International Migration Institute, em Oxford, Reino Unido, encontraram para nomear esse movimento. Alguns investigadores, liderados por Hein de Haas, têm alargado, temporal e espacialmente, a pendularidade que o migrante estabelece, uma vez que as localidades de origem e destino năo estăo, necessariamente, fixadas nos limites internacionais, e os fluxos obedecem a sazonalidades que diferem dos movimentos cotidianos fronteiriços. Ainda assim, nos é particularmente interessante o robusto conjunto de procedimentos metodológicos que eles traçam, especialmente em dois aspectos: o estabelecimento de um sistema migratório; e, a sua estabilidade.

De acordo com de Hass, é necessário compreender que o verdadeiro desafio é elaborar um arcabouço teórico apropriado que seja refinado o suficiente para dar conta das complexidades, bem como das interaçóes do desenvolvimento migratório, desde que nâo se limite ao empirismo estrito e ao relativismo de que tudo "é local e singular" (DE HASS, 2010, p. 240). Entendemos que essa sua asserçăo nos induz à reflexâo quanto aos preparos para os procedimentos metodológicos a serem adotados nos estudos sobre migraçăo internacional.

Nesse sentido, no entendimento de Edward Said (1998), o pesquisador deve ocupar uma posiçăo estratégica perante o objeto da pesquisa. Ou seja, as observaçóes, as análises, portanto, os entendimentos a serem construídos a respeito de determinado objeto dependem da qualificaçăo da posiçấo em que o pesquisador se encontra. Para isso, Said recomenda que o pesquisador deva ter preparo estratégico para que possa encontrar na literatura disponível os referenciais críticos que o conduziráo. Seguindo esse raciocínio, entendemos que os procedimentos metodológicos se principiam na 'revisâo bibliográfica'. Essa expressâo, que se tornou banalizada em diversos projetos de pesquisa, permite encontrar substanciais colaboraçóes para a construçâo de algumas ideias e conceitos a respeito de fronteira, imigrantes, pendularidades, redes e inserçấo social. 
A esse preparo metodológico deve ser acrescido o entendimento de que a migraçăo internacional é um fato social completo, e que a mesma só pode ser efetivada a partir de deslocamentos no espaço físico (SAYAD, 1998). Neste ponto reside uma das mais afloradas e latentes complexidades do tipo de migraçâo internacional pendular. Afloradas no sentido de sua visibilidade e funcionalidades, e latentes por conta da imersăo e da emersăo de seu país e do vizinho que ocorrerem em via dupla. Ou seja, o cotidiano dessas pessoas é tal que tudo em suas vidas, incluindo a ausência e a presença, está diretamente ligado a essa circularidade e suas decorrências. Corroborando com essa ideia, nos ensina Michel Foucher (1991) que o imigrante sabe bem imaginar o que o espera na fronteira, seja qual for a tipologia a ser adotada.

Destacamos que tal deslocamento náo pode ser analisado apenas pelo prisma do ambiente físico, sendo também este um espaço qualificado e possuidor de diversos significados estabelecidos nas relaçōes econômicas, sociais, políticas e culturais (SAYAD, 1998, p. 15). Ou seja, à completude do fato social, a que se referiu Sayad, é acrescida a espacialidade fronteiriça, o que lhe daria um enganoso status de provisoriedade. Tal provisoriedade é desmistificada por meio do reconhecimento de que os estudos sobre migraçôes pendulares internacionais podem ser ampliados a partir da inserçâo da categoria fronteira como elemento de estabilidade do movimento. Isso porque podemos entender esse espaço como: instância, na qual diversas deliberaçôes, oficiais ou năo, ocorrem no processo migratório internacional; e, cenário de interaçôes e conflitos. Nesse sentido, Anderson (1997, p. 26) afirma que a fronteira é palco de açôes políticas, que devem ser consideradas importantes nas análises de instituiçóes e processos que muitas vezes ensejam o estudo do funcionamento de redes que transpassam o espaço fronteiriço.

Em nosso entendimento, aqui reside a necessidade de inserir um debate em relaçăo à migraçăo pendular internacional, uma vez que o estabelecimento de redes no local de destino pode consistir no reconhecimento de vínculos com o local de origem. Desta forma, é necessário que uma espécie de cartografia das migraçóes năo encontre na fronteira sua única circunscriçâo, o que alargaria sua trajetória e reconheceria algo muito mais amplo do que o "local" e o "singular".

Consideramos que os estudos sobre movimentos migratórios pendulares têm suas origens nas observaçóes das dinâmicas populacionais em regióes metropolitanas, cujo núcleo é circundado por outras unidades administrativas que mantêm com ele intrínseca dependência socioeconômica (SOJA, 1993). Portanto, trata-se de um fenômeno cujas raízes sâo profundamente urbanas, onde a questăo do movimento é inerente à da mobilidade. Ou seja, temos que levar em consideraçâo: as estratégias de deslocamentos, os meios para obter o acesso, bem como sua efetivaçăo e os impactos nos respectivos ambientes. Por isso, adotamos pendularidade como a melhor expressăo para o movimento migratório em fronteira que tratamos neste artigo, uma vez que se trata de sistemas estabelecidos em conurbaçōes hierarquizadas, com um desses núcleos desempenhando centralidades.

É importante observar que estudar a presença de migrantes internacionais em fronteira implica em construir análises a partir de um rigoroso apanhado metodológico de trabalho interdisciplinar e polissêmico. Este procedimento nos conduz a propor conteúdos explicativos no sentido de organizar os fatores que “(...) estruturam 
as múltiplas interaçōes dos atores sociais relacionados com a imigraçăo" (MENESES, 2005, p. 114). Náo falamos aqui apenas sobre fazer uso de informaçôes coletadas nas pesquisas de autores de diversas áreas do saber, o que também é válido. Mas, sobretudo, salientamos a necessidade da incorporaçâo de técnicas e métodos de diversas disciplinas, como: etnografia, história oral, espacialidades do movimento, grupos focais, métricas de fluxo, etc.

No âmbito do Núcleo Cidadania Imigrante, ligado ao Laboratório de Estudos Fronteiriços, da Universidade Federal de Mato Grosso do Sul, esse processo migratório tem sido investigado a partir de uma perspectiva na qual se busca a constataçâo de diferenciais em relaçâo aos outros migrantes internacionais consagrados em diversos campos do saber. Partimos do princípio no qual os pendulares têm a outra naçăo como destino cotidiano, ou seja, seu deslocamento é relacionado às atividades por eles desenvolvidas (estudo, trabalho, etc.), e seu retorno ao país de origem ocorre de maneira frequente e regular (OLIVEIRA; CORREAA; OLIVEIRA, 2017).

Por isso a fronteira é tratada como algo estabilizador do processo, uma vez que trabalhamos com a ideia de que formas particulares de internacionalizaçâo se fundem com as condiçóes locais (SASSEN, 1988). Em funçáo disso, nossos resultados aqui apresentados estăo relacionados às pesquisas desenvolvidas na fronteira do Brasil com a Bolívia, mais precisamente em Corumbá, embora algumas das entrevistas tenham ocorrido em solo boliviano. Nosso critério de seleção para entrevistas consistiu em um enquadramento de bolivianos, residentes nas cidades daquele país e que laboram rotineiramente no Brasil, e que fossem maiores de idade.

\section{IMERSÃO E EMERSÃO COTIDIANAS EM CORUMBÁ (BRASIL) E PUERTO QUIJARRO (BOLÍVIA)}

Nesta parte do artigo iremos trabalhar com a zona de fronteira que envolve as cidades de Corumbá e Ladário, no Mato Grosso do Sul, Brasil, e Puerto Quijarro e Puerto Suarez, no Departamento de Santa Cruz, Bolívia. Trata-se de uma semiconurbaçâo com aproximadamente 170 mil habitantes, tendo Corumbá como seu centro dinâmico (Imagem 01). Nesta cidade ocorrem as maiores procuras, tanto laborais como relacionadas às demandas de serviços de saúde e educaçăo, por exemplo. Porém, dela também emanam descolamentos, em direçáo àquelas outras cidades, ligados aos mesmos propósitos, contudo, com intensidades e volumes diferenciados. 
Imagem 01 - Localizaçăo da zona de fronteira em estudo

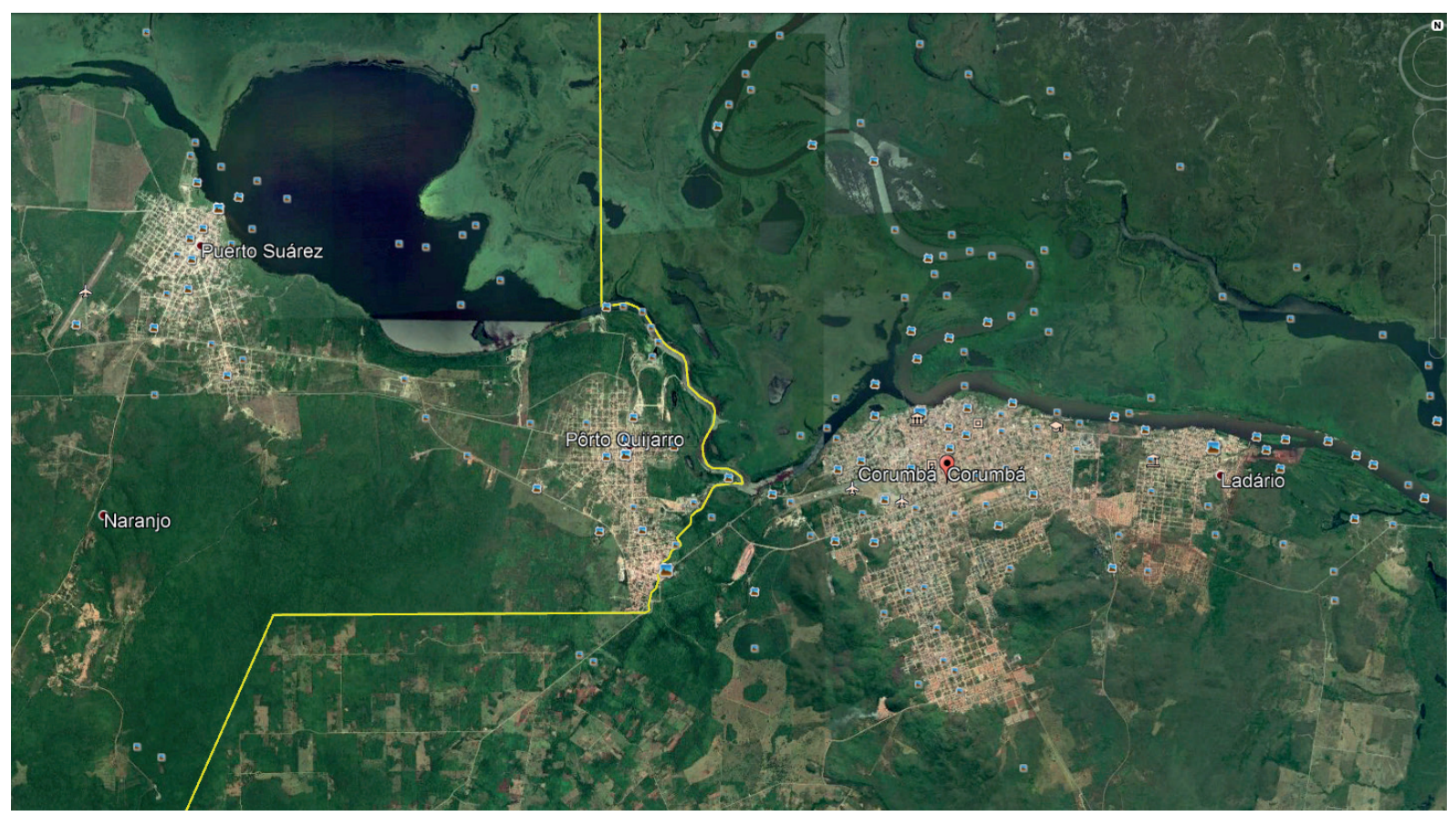

Fonte: Google Earth (2018).

Três dessas cidades nasceram sob a lógica da defesa territorial, uma vez que Corumbá e Ladário, ambas fundadas em 1789, săo fruto da ocupaçăo pós Tratado de Madri (1750), e Puerto Suárez (1875), por sua vez, foi resultado de uma iniciativa estatal de garantir a manutençăo do território a partir de sua ocupaçăo, fruto de incertezas trazidas pela Guerra do Paraguai (1864-1870). Puerto Quijarro (1948) destoa desse enredo, uma vez que sua fundaçăo decorreu da construçáo de uma estaçăo ferroviária na linha que liga aquelas cidades brasileiras a Santa Cruz de la Sierra. Trata-se de uma fronteira cujo crescimento demográfico esteve diretamente ligado às correntes migratórias, sejam as internas de cada país, sejam as internacionais, de variadas origens. Estudos indicam a presença de mais de duas dezenas de nacionalidades convivendo naquele espaço no início do século XX (OLIVEIRA; JUNQUEIRA, 2016), oriundas de quatro continentes.

Dois dos elementos mais importantes da construçâo de Corumbá sâo: sua posiçâo e sua condiçâo fronteiriça. Fazemos tal diferenciaçăo por conta de um entendimento no qual limite e fronteira nâo sâo sinônimos. Enquanto o primeiro denota uma linha imaginária, que é fruto de acordos internacionais, definindo soberanias e demarcando territórios, a segunda é considerada como o resultado de vivências construídas nos ambientes limítrofes, portanto, pertencente aos povos que a compóem (FOUCHER, 1991; MACHADO, 1998). Enquanto o primeiro lhe confere status de vigilância, fiscalizaçăo e observaçóes que implicam em construçôes de visôes estereotipadas, a segunda lhe acrescenta em magia, permitindo sociabilidade, flexibilidades e permissividades inerentes à sua condiçâo. Nesse sentido, ao final do século XIX, se o primeiro conduziu Corumbá a um posto de relevância na defesa do território oeste brasileiro, a segunda, levou as autoridades locais a pedirem medidas às autoridades estaduais para o 
restabelecimento da língua portuguesa em seu cotidiano, que estava dominado pelo espanhol e pelo guarani (SOUZA, 2008).

Outro componente muito importante para compreender esse espaço fronteiriço é o Acordo de Roboré (1958), que fora composto por dez convênios, um protocolo preliminar e vinte notas reversais. Seu objetivo central era traçar uma negociaçăo global que pudesse resolver todos os problemas entre Brasil e Bolívia apagando "(...) ressentimentos e suspeitas" (SOARES, 1975, p. 155). Este Acordo teve como alguns de seus desdobramentos a inserçâo de dez convênios que formataram novos parâmetros comerciais entre ambos os países, como, por exemplo, a instituiçâo de "(...) condiçōes vantajosas para a populaçâo fronteiriça, em especial a em estudo" (OLIVEIRA; ESSELIN, 2015). Um dos mais visíveis resultados daquele Acordo é a facilidade com que se transita na linha limítrofe entre ambos os países e em ambos os sentidos, configurando como 'fronteira aberta', na classificaçâo de Foucher (1991). Isso permitiu que novos fluxos migratórios internos à Bolívia fossem estabelecidos no final da década de 1960 e início da década de 1970, atraídos pelas possibilidades econômicas que existiam naquela regiăo, potencializadas pelo Acordo.

Os fluxos migratórios de bolivianos em direçáo àquela fronteira possuem origens ainda incertas. Contudo, é possível afirmar que o crescimento populacional ganhou intensidade a partir da Guerra do Chaco (1932-1935) e se acentuou no período de construçâo da ferrovia que liga Corumbá a Santa Cruz de la Sierra (1939-1954). Este empreendimento provocou o recrutamento de trabalhadores da regiăo oriental da Bolívia, especialmente, da chamada Chiquitania, envolvendo as cidades de Roboré e San José de Chiquitos (SILVA, 2009). Os níveis de interaçōes entre suas populaçōes fizeram desta fronteira palco de conectividades bastante intensas. Nesse sentido, Silva (2009) assinala que a construçăo da ferrovia redefiniu os parâmetros sociais daquela fronteira. Salienta que aqueles imigrantes teriam chegado à regiầo ou por seus ofícios naquela obra ou nas condiçōes subalternas na dinâmica socioeconômica, como: domésticas, serventes, etc. Para aquele autor, os bolivianos passaram a exercer fortes e amplas influências, indo desde as questōes laborais até as alimentares.

Ainda é impreciso o período em que os bolivianos oriundos do Altiplano começaram a chegar de maneira mais volumosa à fronteira em estudo. Trabalhamos com os indícios de que esses movimentos estariam vinculados à inserçăo daquele país - de maneira semelhante, porém, menos vigorosa do que no Paraguai (ALBUQUERQUE, 2010, p. 67) - nas redes de comércio internacional de produtos oriundos da Ásia, especialmente da China e do Japáo. Esse processo teria seu início nos princípios da década de 1980 (LOIO; MARINI; OLIVEIRA, 2017, p. 227).

$\mathrm{Na}$ atualidade, aquele espaço é palco de tripla tipificaçăo da imigraçăo de brasileiros e bolivianos e outras nacionalidades: os permanentes, que emigraram para o país vizinho ao seu, e lá se estabeleceram; os de passagem, que fazem uso da fronteira como uma instância deliberativa para seu ingresso; e os pendulares, que desenvolvem atividades empreendedoras, laborais ou estudantis no país vizinho, retornando para seu país de origem rotineiramente (CORRÊA, 2016). Também neste aspecto, Corumbá exerce papel central, uma vez que os movimentos pendulares estăo estabelecidos naquela cidade em direçâo a todas as outras e em via dupla. E, no que diz respeito a este artigo, sâo os pendulares bolivianos que prevalecem naquela cidade, embora neste processo também façam parte os brasileiros, peruanos e colombianos, que residem na Bolívia. 
Nessa pendularidade cotidiana é que consiste a imersâo e emersăo em via dupla. Ou seja, ao mesmo passo em que emerge de seu país para imergir em outro, também emerge do país vizinho para uma nova imersâo em seu país de origem. Isso exige do migrante internacional pendular, por um lado, a construçăo de novas sociabilidades e, por outro, de administraçăo daquelas já construídas. Esse movimento, associado à instalaçấo do comércio de produtos oriundos do extremo Oriente, deu à cidade de Corumbá triplo redimensionamento em suas dinâmicas sociais e econômicas: reordenamento hierárquico das moedas de troca, através da vigorosa incorporaçăo do dólar americano nas transaçóes locais; aumento da diversidade e do volume de mercadorias trazidas pelo Pacífico e despachadas de Santa Cruz de la Sierra; e, considerável aumento populacional (LOIO; MARINI; OLIVEIRA, 2017).

\section{UM SISTEMA MIGRATÓRIO INSTALADO}

Para verificar e analisar a existência de fluxos migratórios internacionais pendulares na fronteira em estudo foram realizadas quinze entrevistas no período de 2014 a 2018. Para este artigo foram utilizadas algumas delas, cujos recortes obedeceram a critérios objetivando os seguintes aspectos: a trajetória migratória, que inclui a existência de redes; estratégias e práticas laborais e as lidas com autoridades. Todos os entrevistados trabalham nas feiras livres de Corumbá, devido ao fato de ali estar concentrado o maior número desse contingente populacional, e desempenham naqueles locais diversas tarefas. Todavia, devemos observar que esse espaço năo é o único em que eles atuam, destacando-se, também, os comércios lojistas e trabalhos temporais, como de pedreiros, por exemplo.

Consideramos importante fazer algumas observaçōes a respeito da análise sobre o conteúdo capturado através das entrevistas que realizamos junto aos migrantes pendulares feirantes. Jardim (2015) nos alerta para a possibilidade de riscos de os registros de narrativas conduzirem à reduçâo da vivência no local de origem, isso para que năo ofusquemos conflitos e práticas no processo da decisăo migratória, notadamente familiar. Desta forma, os procedimentos metodológicos utilizados no decorrer das entrevistas assentaram-se no cuidado com os riscos inerentes à história de vida, uma vez que o enredo narrado pode omitir partes significativas para a compreensăo daquilo que queremos capturar. Ademais, os acontecimentos biográficos săo colocaçóes e deslocamentos no espaço social, o que nos exige colocarmo-nos na posiçăo estratégica, a que Said se referia. Ou seja, buscar entender uma dada trajetória de vida năo somente pelo sujeito em si, mas, sobretudo, através de um compromisso na reconstruçăo de espaços e conjuntos de agentes em que esteve relacionado (BOURDIEU, 2001, p. 190). Este cuidado nos permitiu enxergar o sujeito da pesquisa como pertencente à superfície social, ou a capacidade de existir em diversos campos (BOURDIEU, 2001).

A pesquisa evidenciou que a trajetória deles até a fronteira, incluindo a tomada de decisâo, esteve inserida em um contexto familiar. Trata-se de um movimento no qual a família, incluindo suas redes de amizade, ganha importância na contextualizaçâo do processo migratório. Sobre este assunto Solé, Cavalcanti e Parrella (2011) salientam que nos estratos sociais mais baixos da sociedade a decisâo migratória se constitui em uma estratégia familiar de subsistência. Esses autores chamam a atençăo para o fato 
de que a tomada de decisăo está diretamente ligada, na maioria dos casos, à perspectiva de melhora nas condiçóes econômicas e pela falta de atividades ocupacionais no local de origem (SOLÉ; CAVALCANTI; PARRELA, 2011, p. 96).

Exemplo disso está na fala de Yoachin, de 34 anos, nascido em Sucre, onde viveu até os 15 anos, quando se mudou para Santa Cruz. Nessa cidade casou-se, aos 23, e desse matrimônio foram gerados quatro filhos. Conta que ele e sua esposa trabalhavam fazendo pequenos "bicos", ora como faxineiros ora como vendedores de frutas. A decisăo de migrar para a fronteira veio após um convite de uma tia que vivia em Puerto Quijarro, e falava de oportunidades de trabalho nas feiras livres de Corumbá. Segundo ele, entre o convite e a decisâo de migrar foram dois meses de negociaçôes e planejamentos no âmbito familiar. Assim, ele aos 27 anos, ela aos 25 e os quatro filhos com 01, 02, 03 e 04 anos, desembarcam naquela fronteira sabendo ao certo com o que trabalhariam: ele como motorista de Truffi, pequena van utilizada para transporte de pessoas, mercadorias e equipamentos de montagem de barracas, ela como babá dos netos da tia dele.

Carmín, 62 anos, tia de Yoachin, nasceu em La Glorieta, um pequeno povoado próximo a Sucre. Conta que ainda criança mudou-se com os pais para aquela cidade, onde viveram até os 18 anos, quando se casou. Como seu marido morava em Santa Cruz, e trabalhava como operador de máquinas, ela migrou para lá, onde laborava como costureira e cuidava de seus três filhos. Aos 30 anos ficou desempregada e viúva, e viu sua vida financeira entrar em colapso. Segundo suas palavras isso a "levou" a trabalhar como vendedora de frutas na Feria Los Pozos, quando perdeu um de seus filhos, vitimado por um atropelamento.

Em 1990, quando estava com 36 anos, um irmăo a chamou para trabalhar consigo na feira livre de Corumbá, foi quando se reuniu com os filhos e decidiram mudar de cidade. Quatro dias após o convite eles desembarcaram e começaram a trabalhar. Conta que no início teve muitas dificuldades, principalmente, em manusear três moedas (peso, cruzeiro e dólar) e compreender o português. Dez anos depois, com um pequeno capital conseguiu comprar uma Truffi e trabalhar fazendo frete, porém náo podia dirigir, porque nâo o sabia, sendo motorista o seu filho mais velho. Em 2010, contava com dois veículos, quando convidou seu sobrinho para migrar.

Ainda sobre decisôes migratórias que se estabeleceram no âmbito familiar, apresentamos os relatos de Rosa, Edwirges e Maria. Rosa, 38 anos, nasceu em Escalona, povoado localizado no Departamento de La Paz, onde viveu até os 12 anos de idade, quando se mudou para Cochabamba, onde trabalhava como empregada doméstica na casa de uma família. Aos 14 anos, mudou-se para Santa Cruz de La Sierra para morar com uma de suas irmás que trabalhava naquela cidade. Posteriormente, já casada e com um filho de 2 anos, Rosa permanecia na profissăo de empregada doméstica, enquanto seu marido trabalhava em uma sapataria e diante das dificuldades enfrentadas pelo casal, uma prima de Rosa que residia em Puerto Quijarro e trabalhava nas feiras livres de Corumbá, fez o convite para que ela e sua família se mudassem. A inserçăo de Rosa nas feiras também ocorreu através de sua prima, que viabilizou um pequeno espaço para que ela iniciasse seus negócios. A imigrante e o marido trabalham com a venda de roupas usadas e ela relata que iniciou suas atividades com uma pequena banca e um capital equivalente a $\mathrm{R} \$ \mathbf{1 0 0 , 0 0}$. Além de ter estabelecido seu comércio nas feiras de Corumbá, Rosa possui um pequeno negócio em sua casa em Puerto Quijarro, o qual administra no período em que năo está trabalhando nas feiras. 
A imigrante demonstrou temor com relaçâo às autoridades brasileiras e relatou que já teve mercadorias apreendidas duas vezes pela Receita Federal em depósitos em Corumbá. Ela contou que em uma das ocasiōes foram devolvidas 5 bolsas de mercadorias pelas autoridades e em outra nada foi devolvido. $O$ trato com autoridades merece ser melhor avaliado em estudos futuros, pois é um dos campos mais tensos nas relaçóes entre imigrante e agentes da burocracia, pois tem a mercadoria como elemento a mais na composiçấo do cenário e de seus resultados. Neste aspecto, um dos servidores da $\mathrm{RF}$ apontou que existia uma pressâo do poder público local e dos comerciantes para que o órgâo fizesse mais operaçôes junto aos feirantes. Contudo, afirmou năo dispor de efetivo para "ficar fiscalizando feira". Desse modo, ocorriam apenas as operaçōes em locais e em situaçōes pontuais, como nos depósitos utilizados pelos feirantes.

Edwirges, de 61 anos, nascida em Oruro, relatou que se mudou para Puerto Suárez a convite de sua irmă, que havia se mudado para cidade e já havia se estabelecido na regiâo. Inicialmente, Edwirges trabalhava com atividades comerciais no lado boliviano, posteriormente, amigas que já trabalhavam na feira livre facilitaram seu ingresso neste espaço. Inicialmente, trabalhava com a venda de roupas usadas, contudo, Edwirges afirmou que teve um problema de saúde que a afastou do trabalho e que definiu algumas mudanças em sua trajetória laboral. Como ficou desprovida de capital após sua enfermidade, ao retornar para a feira Edwirges passou a vender folhagens, porque um dos seus filhos tem uma horta e relatou que nâo era necessário grande investimento para trabalhar com este tipo de produto.

Por sua vez, Maria, 33 anos, nascida em Cochabamba, mudou-se para Puerto Suárez aos 14 anos, levada pela madrinha. Maria relatou que sua madrinha possuía uma pequena lanchonete e ela a auxiliava fazendo salgados e atendendo os clientes. Ao completar 16 anos, Maria conheceu seu marido e como sua madrinha era contra o relacionamento, ela relata que fugiu para mantê-lo. Foi a partir de entăo que ocorreu seu ingresso nas feiras de Corumbá, já que sua sogra trabalhava com este tipo de comércio, bem como as esposas de seus cunhados. Inicialmente ela relatou que trabalhava para a sogra, vendendo verduras, legumes e frutas. Posteriormente, a sogra a ajudou a colocar sua própria barraca para que trabalhasse sozinha, vendendo os mesmos tipos de produtos.

Analisando os contextos das migraçōes internacionais que já verificamos, consideramos relevante realizar reflexâo a respeito de suas efetivaçōes se darem através de cadeias migratórias ou de redes de migraçăo. De acordo com Charles Tilly, cadeias migratórias ocorrem quando um conjunto de sujeitos se move de um lugar para outro sob o apoio, estímulo, confiança e informaçóes de parentes ou conterrâneos no destino (TILLY, 1978). Para Massey (1988), as redes migratórias săo complexos laços que ligam os sujeitos da migraçấo, os que já migraram e os que nâo migraram, através de vínculos familiares, conterrâneos e de amizade. $\mathrm{O}$ uso de cadeias ou de redes, de acordo com Oswaldo Truzzi, visa destacar as circunstâncias nas quais se decide migrar após o recebimento de informaçôes sobre o local de destino (TRUZZI, 2008, p. 203).

Neste processo de instalaçăo e consolidaçăo de redes migratórias há um componente que potencializa os laços e efetiva as comunicaçôes de forma mais rápida: as redes sociais e o Whatsapp, aplicativo de mensagens que permite trocas instantâneas de textos, fotos e áudios. Carmín, por exemplo, utiliza esse aplicativo para gerenciar 
os negócios e comunicar-se com a família, tanto os membros que residem na fronteira como os que estăo em outros lugares da Bolívia. De acordo com ela, foi através desse recurso que "conseguiu" convencer Pinot, outro sobrinho, residente em Santa Cruz, a migrar para aquele destino.

Pinot, de 26 anos, chegou a Puerto Quijarro em 2014, para trabalhar como montador de bancas de feirantes. Conta que seu "sueldo" inicial era de 150 dólares americanos e que significava o dobro do que conseguia ganhar em Santa Cruz. Ainda de acordo com ele, na atualidade seus ganhos chegam a 400 dólares americanos. Naquela fronteira casou-se com Julieta, 25 anos, filha de Andrés, 49 anos, argentino, com Norma, 42 anos, boliviana, natural de Yacuiba, Departamento de Tarija. Julieta conta que migrou para lá acompanhando os pais. Essa família mudou-se a convite do irmăo da mâe, que possui um sítio em Yacuses, distante cerca de 50 quilômetros do limite Bolívia-Brasil. Atualmente, Andrés e Norma possuem um pequeno lote de terreno em Puerto Quijarro, onde cultivam hortaliças para vender nas feiras de Corumbá. O casal conta que todo o processo de seu movimento migratório, desde o convite, passando pelo convencimento e pela decisâo e efetivaçáo ocorreu por meio de Whatsapp.

O Whatsapp é um aplicativo que dá liberdade para a criaçăo de grupos que podem tornar ágil o diálogo, possibilitando que pessoas, independentemente da posiçấo geográfica e social, com interesses e hábitos em comum, se comuniquem com extrema facilidade (MORAES; NERCOLINI, 2014). Isso nâo passa sem efeitos na vida cotidiana, criando novos parâmetros de sociabilidade, incluindo aproximaçôes e distanciamentos, bem como potencializando os formatos das redes de migraçâo (BRIGNOL, 2015).

Um componente importante para o migrante internacional pendular em fronteira é o trato com as autoridades, especialmente quanto às do país vizinho. Como se trata de pessoas que transitam cotidianamente para trabalhar, principalmente, no comércio, o fluxo costuma causar apreensōes, uma vez que, além dos próprios migrantes, há mercadorias e equipamentos de trabalho, como os apetrechos para instalar as bancas nas feiras. Neste aspecto, ganha relevo Juan, 36 anos, nascido em Roboré, Departamento de Santa Cruz, que possui um Truff, com o qual realiza fretes, carregando mercadorias, bancas e feirantes desde Puerto Quijarro até Corumbá e Ladário. Considera-se um homem bem sucedido, uma vez que ele se classificou como um empreendedor que atingiu uma "cierta estabilidade", como ele próprio disse. Afirma que, em média, transporte três feirantes por dia, contando com suas mercadorias e armaçóes da banca. No que diz respeito ao traslado, afirma que no início de suas atividades, há dez anos, sentia muita apreensăo, uma vez que se as mercadorias fossem apreendidas, perderia fregueses e seu negócio minguaria, haja vista que os "feirantes se falam né?". Conta que com o passar do tempo foi "conhecendo como as coisas funcionam na fronteira" e comenta que ficou mais à vontade quanto à fiscalizaçăo, principalmente porque os feirantes optaram por alugar imóveis em Corumbá e ali fazer o depósito de suas mercadorias. Assim, segundo Juan, as mercadorias săo transportadas aos poucos, diminuindo os riscos de grandes perdas e ganhando certa invisibilidade perante as autoridades. 


\section{CONSIDERAÇÕES FINAIS}

O presente estudo sobre a imigraçăo pendular em fronteira mostrou o quanto é complexa a situaçấo desses sujeitos no espaço em que eles vivem, incluindo a habitaçâo e o laboral desenvolvido por eles. As pesquisas sobre os movimentos migratórios necessitam considerar como relevante a existência desta pendularidade, uma vez que sua invisibilidade proporciona uma série de prejuízos àqueles sujeitos, notadamente ligados à questăo documental.

Com a inserçấo da categoria fronteira, bem como da constataçăo de sua funçăo estabilizadora do processo migratório, é possível enxergar melhor o fenômeno. A espacialidade é o que nutre a existência da pendularidade. Nesse sentido, os sujeitos de nossa pesquisa têm acrescentados às suas vidas uma carga de complexidade extra: emersáo e imersáo cotidianas, e em ambos os sentidos de entrada e de saída. Essa espécie de 'mapa mental' que eles possuem lhes permite administrar essa espacialidade e traçar estratégias que visem assegurar-lhes sobrevivência e, em alguns casos, expansáo dos negócios.

Novos desafios săo postos para futuras pesquisas. Assim, é muito importante que possamos dar passos em direçấo a três aspectos. Primeiro, é necessário que apliquemos esses procedimentos metodológicos junto aos que vivem no Brasil e trabalham e/ou estudam na Bolívia. Segundo, necessitamos verificar melhor o impacto que eles produzem sobre o espaço fronteiriço, considerando o trânsito, as vizinhanças nos locais em que laboram, além de usos de sistemas públicos de saúde e de educaçăo. E, terceiro, averiguar as consequências da indocumentaçăo, principalmente, relativa à questâo previdenciária de ambos os países, que atinge essa parcela pendular da populaçâo, visando compreender os nichos de renúncia e de exclusáo a que estáo sujeitos. 


\section{REFERÊNCIAS}

ALBUQUERQUE, L. J. A Dinâmica das Fronteiras: os brasiguaios entre o Brasil e o Paraguai. Săo Paulo: Annablume, 2010.

ANDERSON. M. "The Political Sciences and Frontiers". In: GANSTER, P.; SWEDLER, A.; SCOTT, J.; DIETER-EBERWEIN, W. (orgs.) Borders and Border Regions in Europe and North America. San Diego University Press, Institute for Regional Studies of the Californias, 1997, pp. 27-46.

BOURDIEU, P. "A Ilusāo Biográfica". Trad. de Luiz Alberto Monjardim et alli In: FERREIRA, M. M.; AMADO, J. (orgs.) Usos \& Abusos da História Oral. $4^{a}$ Ediçăo. Rio de Janeiro, Editora da FGV, 2001, pp. 183-192.

BRIGNOL, L. D. “Usos sociais das TICs em dinâmicas de transnacionalismo e comunicaçăo migrante em rede: uma aproximaçăo à diáspora senegalesa no sul do Brasil". In: Comunicaçăo, Mídia, Consumo, Săo Paulo, v. 12, n. 35, 2015, pp. 89-109.

CORREAA, Jaqueline M. O Mestrado Profissional em Estudos Fronteiriços em perspectivas de inserçăo social: avaliaçóes sobre a implantaçăo do Circuito de Apoio ao Imigrante. Dissertaçăo de Mestrado em Estudos Fronteiriços. UFMS/CPAN, 2016. 89 p.

DE HASS, H. Migration and Development: A Theoretical Perspective. In: International Migration Review. V. 44, n. 01, 2010, pp. 227-264.

DRIESSEN, Henk. "The 'new immigration' and the transformation of the European-African frontier. In: WILSON, Thomas M.; DONNAN, Hastings (orgs.). Border Identities. Nation and State at International Frontiers. Cambridge, Cambridge University Press, 1998, pp. 96-116.

ESPÍRITO SANTO, N. P. Unidades de Saúde na Bolívia: a realidade na fronteira com o Brasil em Mato Grosso do Sul. Dissertaçâo de Mestrado. Programa de Pós-Graduaçăo Mestrado em Estudos Fronteiriços, UFMS, 2013.

FÁRFAN, Carolina R. "Trabajadores Migrantes en la Frontera Sur de México. Caracterización del Trabajo Temporal Centroamericano en el Soconusco". In: HERNANDEZ, A. H.; CAMPOS-DELGADO, A. E. (Orgs.) Líneas, Límites y Colindancias. Mirada a las Fronteras desde América Latina. Tijuana: El Colegio de la Frontera Norte; México, D. F., CIESAS, 2015, pp. 271-298.

FOUCHER, M. Fronts et Frontières. Paris, Fayard, 1991.

JARDIM, D. F. Estratégias de imigraçâo em tempos da globalizaçăo: os palestinos e suas viagens internacionais. In: Cartografia da Imigraçáo: Interculturalidade e Políticas Públicas. Porto Alegre: Editora da Universidade, 2007.

LOIO, J. A. M.; MARINI, J. F. M.; OLIVEIRA, M. A. M. “Imigrantes Bolivianos da Planície e do Altiplano em Regiăo de Fronteira: Distinçōes Pregressas em Solidariedade Seletiva". In: Revista Geopantanal, Corumbá, MS, Número Especial, 2017, pp. 219-232. 
MACHADO, L. O. Limites, Fronteiras, Redes. In: T.M.Strohaecker et alli (orgs.). Fronteiras e Espaço Global, AGB-Porto Alegre, Porto Alegre, 1998, p.41-49.

MASSEY, Douglas. (1988), “Economic development and international migration in comparative perspective". Population and Development Review, 14: 383-413.

MENESES, G. A. Violencias asociadas al Cruce Indocumentado de la Frontera MéxicoEstados Unidos. In: Nueva Antropología, 2005, pp. 113-129.

MORAES, L. A. de; NERCOLINI, M. J. “Tecnologias Móveis, Vida Cotidiana e Comunicaçâo em Massa" In: Mídia e Cotidiano, n. 05, dez. 2014, 1-14.

OLIVEIRA, M. A. M.; JUNQUEIRA, N. M. “Representaçōes sociais de sírios e libaneses em Corumbá, MS: comércio, casamento e cemitério". In: Revista Transporte y Territorio. Buenos Aires, n. 15, pp. 388-403, 2016.

OLIVEIRA, M. A. M.; CORRÊA, J. M.; OLIVEIRA, J. C. “Imigrantes Pendulares em Regiấo de Fronteira: semelhanças conceituais e desafios metodológicos". In: Direitos Culturais, Santo Ângelo, v. 12, n. 27, pp. 91-108, maio/ago 2017.

OLIVEIRA, T. C. M.; ESSELIN, P. M. “Localizando as Condiçōes Pretéritas e as relaçōes Correntes na Complexa Fronteira Brasil-Bolívia". In: Geosul, Florianópolis, v. 30, n. 60, pp. 125-163, 2015.

PIZARRO, José A. G. "Notas sobre la Inmigración Argentina en la Precordillera Antofagastina durante el Ciclo Salitrero". In: Estudios Atacameños, n. 42, 2011, pp. 189-204.

SAID, Edward S. Representaçōes do Intelectual. Trad. de Milton Hatoum. Săo Paulo, Cia das Letras, 2005.

SASSEN, S. The Mobility of Labor and capital:AStudy in International Investment and Labor Flows. Cambridge University Press, 1988.

SAYAD, A. A Imigraçáo ou os paradoxos da alteridade. Trad. Cristina Murachco, Edusp, 1998.

\section{SILVA, G. J. A Presença Kamba-Chiquitano na Fronteira Brasil-Bolívia}

(1938-1987): identidade, migraçóes e práticas culturais. Tese de Doutorado. Programa de Pós-Graduaçăo em História, Faculdade de História, Universidade Federal de Goiás. 2009.

SOARES, A. T. História da Formaçăo das Fronteiras do Brasil. 3 ed., Rio de Janeiro, Conquista, 1975.

SOJA, E. W. Geografias pós-modernas: a reafirmaçăo do espaço na teoria social crítica. Rio de Janeiro: Jorge Zahar, 1993. 
SOUZA, J. C. Sertăo Cosmopolita: tensóes da modernidade de Corumbá (18721918). Săo Paulo, Editora Alameda, 2008.

TILLY, Charles. "Migration in Modern European History". In: MCNEILL,William H. \& ADAMS, Ruth S. (orgs.). Human migration, patterns and policies. Indiana University Press, 1978, pp. 48-72.

TRUZZI, O. "Redes em processos migratórios". In: Tempo Social, Revista de Sociologia da USP, v. 20, n. 01, 2008, pp. 199-218. 